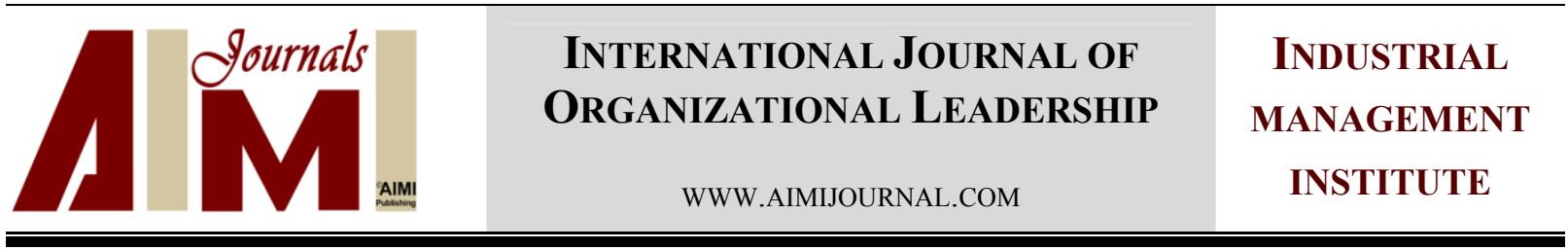

\title{
Subordinate responses to leadership: Evidence from an emerging market firm
}

\author{
Lydia Arbaiza, Jorge Guillén* \\ Esan Graduate School of Business
}

\begin{tabular}{|c|c|}
\hline & ABstract \\
\hline $\begin{array}{l}\text { Keywords: } \\
\text { Moral, Authoritarian, } \\
\text { Benevolent and } \\
\text { Transformational } \\
\text { Leadership, Subordinate } \\
\text { Responses }\end{array}$ & $\begin{array}{l}\text { This paper was conducted to examine the effect of paternalistic and Western leadership } \\
\text { style using a sample of } 326 \text { subordinates. Due to insufficient number of studies about the } \\
\text { type of relationship between subordinates' responses and leadership type, this study aimed } \\
\text { to determine whether paternalistic and Western leadership has a positive impact on }\end{array}$ \\
\hline $\begin{array}{l}\text { Received } \\
14 \text { April } 2016\end{array}$ & Peru, such as Banking, Informational Technology, Commerce, Supply Chain, Construction \\
\hline $\begin{array}{l}\text { Received in revised form } \\
28 \text { August } 2016\end{array}$ & $\begin{array}{l}\text { paternalistic leadership such as benevolent leadership, moral leadership, and authoritarian } \\
\text { on subordinate responses. The findings revealed that paternalistic leadership had a positive }\end{array}$ \\
\hline $\begin{array}{l}\text { Accepted } \\
20 \text { September } 2016\end{array}$ & $\begin{array}{l}\text { influence on compliance and gratitude while transformational leadership had a positive } \\
\text { influence on gratitude. The survey was limited to Lima due to the current researcher did not }\end{array}$ \\
\hline $\begin{array}{l}\text { Correspondence: } \\
\text { larbaiza@esan.edu.pe }\end{array}$ & $\begin{array}{l}\text { have access to subordinate interviews throughout the Latin American Region. The results } \\
\text { of this study were relevant to leadership theory and practices that can be implemented in } \\
\text { Peruvian firms. }\end{array}$ \\
\hline
\end{tabular}

CAIMI Journals

There are different types of leadership and therefore it is important to identify the types of leadership in order to gain and maintain positive results in subordinates and align subordinates' objectives or goals throughout the organization. Leadership enables an organization to change and emphasize on expanding the studies that investigate the impact of leadership behaviors on the firms' performances. Leadership types vary with the kind of people the leaders deal with them and include authoritarian, paternalistic, democratic, Laissez-Faire, and transformational (Silin, 1976; Yukl, 2000). An authoritarian leadership style is exemplified by a police officer or teacher and maintains strict control over followers. Direct supervision is a key factor in maintaining a successful environment and followership while fear is considered as a key 
variable which prevents productivity among the followers. Therefore, authoritarian leaders maintain their close supervision over their subordinates. Generally, authoritarian leaders are focused on efficiency, whereas other style, such as the democratic style is considered as a hinder for firm's progress (Graen, Novak, \& Sommerkamp, 1982).

A paternalistic leader acts like a father figure and takes care of his subordinates as a parent do. In response, this type of leader receives a great degree of trust and loyalty from his/her people. Also, the workers under this style of leader are expected to become totally committed to the beliefs of their leaders and do not work independently. There is a solid-type relationship between the leaders and their subordinates and therefore the workers attempt to stay with the company for a longer period of time. This encourages them to communicate confidently about their problems with their leaders because they assure them to help (Van Vugt, Hogan, \& Kaiser, 2008). A democratic leader shares decision-making and problem solving activities with his leadership coworkers. This style of leadership includes discussion, debate, and sharing of ideas. This kind of leaders shares their coworkers in the process of their making decisions and encourages their subordinates to feel good about their involvements and problems. Involvement of all members in decision-making is an inherent feature of the democratic leadership. The required time for making decisions can be significantly longer in comparison to other different leadership types such as authoritarian. Moreover, the democratic style of leadership requires guidance and control by a specific leader (Bass, 2000).

In Laissez-faire leadership style, all the rights and power are fully given to the workers to make decisions along with the autocratic and the democratic leadership styles (Lewin \& Lippiit, 1938). The Laissez-faire leadership style is occasionally known as hands off leadership style because the leaders can delegate the prioritizing tasks to their followers while providing little or no direction. If the leader withdraws too much from his followers, a lack of productivity, cohesion, and satisfaction may be evident in their performances. Transformational leadership is a style of leadership in which the leader can identify the needed help and create a vision. This kind of leader inspires their workers and creates a vision to guide the changes. This type of leadership also enhances the motivation, morale, and job performance of its followers through applying a variety of mechanisms such as organizational identification, acting as a role model for inspiring the workers and increasing their level of interest to achieve the firm's objectives, inspiring the followers to accept new goals and take giant steps for their work, and finally understanding the strengths and weaknesses of its followers. A transformational leader aligns followers some tasks or duties to enhance their performances. In contrast to Laissez-faire leadership style, the outcome of transformational leadership is always positive (Eagly, Johannesen-Schmidt, \& Van Engen, 2003). This type of leadership is described in the literature as Western leadership. However, these 5 types of leadership do not occur separately in real life. According to Farh and Cheng (2000), paternalistic leadership has three constituent elements including authoritarian leadership, benevolent leadership, and moral leadership. In authoritarian leadership, subordinates construct a lofty image of their leaders and therefore they can assert absolute authority and control over their subordinates. These subordinates intend to respond with obedience, compliance, respect, and fear. In benevolent leadership, the leaders show importance in their actions mostly through individualized care about their subordinates; therefore, their subordinates respond them with gratitude and reciprocity. Moral leadership is 
characterized by unselfishness and providing an example that is identified and imitated by subordinates. Table 1 summarizes the study of Farh and Cheng (2000) and illustrates the response of subordinates toward paternalistic leadership and its key alternatives:

Table 1

Responses to Paternalistic Leadership

\begin{tabular}{|c|c|}
\hline Authoritarianism & Subordinate Response \\
\hline Authority and Control & Compliance \\
\hline $\begin{array}{l}\text {-Unwilling to delegate } \\
\text {-Top-down communication } \\
\text { - Information secrecy } \\
\text { - Tight control }\end{array}$ & $\begin{array}{l}\text {-Shows public support } \\
\text {-Avoids open conflict with boss } \\
\text {-Avoids expressing dissension }\end{array}$ \\
\hline Underestimation of Subordinate Competence & Obedience \\
\hline $\begin{array}{l}\text { - Ignores subordinate suggestions } \\
\text {-Belittles subordinate contributions }\end{array}$ & $\begin{array}{l}\text {-Accepts leader's directives unconditionally } \\
\text {-Loyal to leader } \\
\text {-Trust in leader }\end{array}$ \\
\hline Image Building & Respect and Fear \\
\hline $\begin{array}{l}\text {-Acts in a dignified manner } \\
\text {-Exhibits high self-confidence } \\
\text {-Manipulates information }\end{array}$ & $\begin{array}{l}\text {-Shows deep respect } \\
\text {-Expresses both fear or awe of the leader }\end{array}$ \\
\hline Didactic Behavior & A Sense of Humility \\
\hline $\begin{array}{l}\text {-Insists on high performance standards } \\
\text {-Reprimands subordinates for poor performance } \\
\text {-Provides guidance and instructions for improvements }\end{array}$ & $\begin{array}{l}\text {-Willing to confess mistakes } \\
\text {-Takes leader's instructions seriously } \\
\text {-Corrects mistakes and improves }\end{array}$ \\
\hline Benevolent Leadership & \\
\hline Individualized Care & Shows Gratitude \\
\hline $\begin{array}{l}\text {-Treats employees as family members } \\
\text {-Provides job security } \\
\text {-Assists during personal crises } \\
\text {-Shows holistic concern } \\
\text {-Avoids embarrassing subordinates in public } \\
\text {-Protects even grave errors of subordinates }\end{array}$ & $\begin{array}{l}\text {-Never forgets leader's favors } \\
\text {-Strives to reciprocate } \\
\text {-Sacrifices self-interest for leader } \\
\text {-Takes assignments seriously } \\
\text {-Meets leader's expectations } \\
\text {-Works diligently }\end{array}$ \\
\hline Leader Morality and Integrity & \\
\hline Unselfishness & Identification \\
\hline $\begin{array}{l}\text {-Does not abuse authority for personal gain } \\
\text {-Does not mix personal interests with business interests } \\
\text {-Places collective interests ahead of personal interests } \\
\text { Lead by example } \\
\text {-Acts as an exemplar in work and personal conduct }\end{array}$ & $\begin{array}{l}\text {-Identifies with leader's values and goals } \\
\text {-Internalizes leader's values } \\
\text { Modeling } \\
\text {-Imitates leader behavior }\end{array}$ \\
\hline
\end{tabular}

Farh and Cheng (2000) proposed a model based upon the subordinate responses of identification, compliance, and gratitude. Authoritarian leadership evokes a stronger response of dependence and compliance while benevolent leadership induces more gratitude and repayment and moral leadership results in respect and identification. This study focused on how paternalistic and Western leadership exercises had a positive impact on the subordinates such as identification, compliance, and gratitude. This study is relevant to human resource policies and aligning the objectives between subordinates and the leader of a firm. It also examined the effects of transformational leadership and its impacts on subordinates' responses.

\section{Leadership in Latin America}

Some management practices in Latin America may incorporate some aspects of Western or transformational leadership. In contrast to the Chinese literature discussed above, it has been suggested that servant leadership is still very popular in the Latin American (Anderson, 2006; Cote, 2003; Ruloff, 2006; Segura, 2005; Serrano, 2006). The later studies by the authors cite 
empirical research in Latin America supporting in this field, despite historical skepticism towards the concept. McIntosh and Irving (2010) initially indicated that Amaral described servant leadership as utopian, although other theorists have modified and expanded his findings. Patterson's (2003) model of servant leadership includes seven virtuous constructs of love, humility, altruism, vision, trust, empowerment, and service. This concept is very similar to the leadership of Jesus as the model leader. The servant-leader is used for sharing power, placing the needs of others first, and helping people to develop and perform as highly as possible. House et al. (2004) believed that Latin America is a prime example of servant leadership and Caudillo is known as the most charismatic leader of Latin America. They stated that much remains to be learned about the process by which the charismatic leaders affect on their followers. According to Peruvians, the primary means by which leaders affect followers is usually oratory and rhetoric. There are different examples of this kind of leadership in Peruvian management in different fields of study Mayers (1976). Nida (1974) stated that Jesus, as a popular model of servant leadership, is rejected by the Latin American population because he lacks desirable traits such as numerous sexual exploits or conquests, heavy alcohol consumption, and fighting prowess. Davila and Elvira (2005) identified paternalistic leadership in the Latin American context. Human resource management practices are based upon rewards in this context to provide a basis for paternalistic leadership. The late authors studied how paternalistic leadership influences human resource management practices in the Latin American context. Furthermore, paternalistic leadership has been identified as a way of living in certain countries such as Mexico. Boyer (2000) stated that this type of leadership is derived from traditional family roles and Catholic precepts which compel employers to act as caretakers to form a family from their workers. However, all authors did not guarantee that these results are true for every country within the Latin American context.

The labor markets in Latin America are similar to the Chinese labor markets; for instance, a significant proportion of the labor force is treated informally and their salaries are mostly below the minimum wages. In addition, there is an increase in tax evasion and low coverage for retirement pensions (Arbaiza, 2009). This study attempted to determine if there was a significant positive relationship between paternalistic leadership and the subordinates' responses. No research has been conducted in Peru and thus this will be a complementary study for the Latin American literature. It should be useful to determine if paternalistic leadership, in contrast to Western leadership, has a positive influence upon subordinates.

\section{The Empirical Model of Leadership}

The dependent variables of this study were identification, gratitude, and compliance. The explanatory variables were also classified into two groups including control and independents. The control variables include gender, education, time, and position of the subordinates. This set of variables has been widely used in the literature by authors such as Cheng, Chou, and Farh (2004) who conducted empirical research studies in the leadership. They expected that the indicator of gender had a positive impact because men may positively respond to the dependent variables. Furthermore, education, time, and position should have positive signs due to the positive relationship between these sets of variables and the dependent variables. The response of a subordinate with higher levels of education, longer working experience, and a better 
position toward the exercising leadership is always positive. According to Cheng, Chou, and Farh (2004), these control variables are considered as the proxies for human capital and power and may influence on a person's reactions toward his/her leader according to the magnitude of higher education system, gender, and position in the firm. The variables namely authoritarian, benevolent, and moral which are the key forms of paternalistic leadership were measured using a Likert Scale and considered as independent variables. To capture any effect of Western leadership, a transformational measure of leadership was also included in the Likert scale. It was supposed that the signs of these variables to be positive and significantly related to the subordinates' responses of gratitude, identification, and compliance. These variables are also dependent and measured by using Likert Scale. The key variables related to paternalistic leadership and Western leadership proxy (transformational leadership) are included in the literature discussed previously.

\section{Research Question}

In line with the discussion above, the following research question was formulated:

How do paternalistic and Western leadership exercises have a significant positive impact on the subordinates such as identification, compliance, and gratitude?

\section{Method}

A survey was conducted to study the performance of students from the MBA program at the ESAN Graduate School of Business. The statistical population of the study was consisted of managers, bosses, deputy managers, and analysts. The survey included several questions about the respondents' feelings and different leadership types or styles they have experienced. Table 2 shows the descriptive statistics of the respondents. According to Table 2, most of the respondents were men (about 56.44 per cent). To ensure research samples reflect and guarantee diversity, about 43.56 per cent of women were also involved in different activities of business such as information technology (IT), manufacturing, commerce, finance, real estate, supply chain, and health and legal firms.

Table 2

Descriptive Statistics of Respondents

\begin{tabular}{lcccc}
\hline Variables & & Frequency & Percent & Cumulative Percentage \\
\hline \multirow{3}{*}{ Gender } & Female & 142 & 43.56 & 43.56 \\
& Male & 184 & 56.44 & 100 \\
& Total & 326 & 100 & 2.19 \\
& & & 20.44 \\
Education & Ph.D. & 6 & 2.19 & 48.54 \\
& Secondary & 50 & 18.25 & 54.74 \\
& Master & 77 & 28.1 & 100 \\
& High School & 17 & 6.2 & 5.18 \\
Pniversity & 124 & 45.26 & 74.39 \\
& Total & 274 & 100 & 77.44 \\
& Director or Senior & 17 & 5.18 & 100 \\
\hline
\end{tabular}


In addition, the educational levels of respondents were primarily master's and bachelor's degrees and only 2.19 per cent of the respondents earned a $\mathrm{PhD}$. The majority of the managers and subordinates, about 73.36 per cent of the sample, had bachelor's and master's degrees and just 5.18 percent of the firm were allocated to the position of either director or senior manager and therefore the firm was held by minority groups. First-line and middle managers assigned 3.05 and 22.56 per cents to themselves respectively while employees allocated only 69.21 per cent of the sample to themselves. To test the hypothesis of study which stated how paternalistic and Western leadership exercises had a positive impact on the subordinates such as identification, compliance, and gratitude, all the variances in the firm were calculated and interpreted.

\section{Results}

Model 1 was tested for the aim of this paper and the results were presented in Table 3.

Model (1)

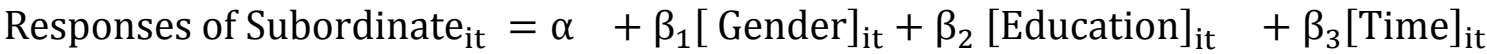

$$
\begin{aligned}
& +\beta_{4}[\text { Position }]_{\text {it }} \beta_{4}[\text { Benevolent }]_{\text {it }}+\beta_{4}[\text { Moral }]_{\text {it }}+\beta_{4}[\text { Authoritarian }]_{\text {it }} \\
& +\beta_{4}[\text { Trasnformational }]_{\text {it }}
\end{aligned}
$$

In this model, responses of the subordinate refer to any type of leadership or control variable such as identification, compliance, and gratitude. Gender stands for the surveyed individual i while education refers to their level of education of the surveyed i. Time, position, benevolent, moral, authoritarian, and transformational stands for time employed by the firm for the surveyed $i$, the position of the surveyed $i$, the type of leadership experienced by the surveyed $i$, the type of leadership experienced by the surveyed i, and the type of leadership experienced by the surveyed i, respectively.

The benevolent, moral, and authoritarian leadership styles are the key factors for paternalistic leadership while transformational management style captures its attention to the attributes of Western leadership. Table 3 presents the results of the quantile regression for the effect of authority which is a widely used technique in the literature to analyze qualitative data or surveys through using Likert Scale. Although Cheng et al. (2004) and Farh and Cheng (2000) did not use this type of technique, it is considered as the most appropriate technique for Peruvian sample of this study $(\mathrm{N}=326)$.

The sample was divided into population quintiles of $0.25,0.5$, and 0.75 , respectively. In this study, the dependent variables were identification, compliance, and gratitude. The results showed that the variables such as education and gender had a significant positive impact on the subordinate respondents. Furthermore, benevolent leadership is a key element for paternalistic leadership and had a significant positive impact on the subordinates. In terms of compliance and gratitude, the results of the study were consistent with the findings of Cheng, et al. (2004), Farh and Cheng (2000), and Tornell, Westermann, and Martinez (2004). The results also revealed that Western leadership style also had an impact on gratitude while identification was not influenced by paternalistic leadership or Western leadership. The results of this study also 
demonstrated that how the organizational behavior operated within the observed Peruvian firms which were in contrast to the results of Tornell et al. (2004) who assessed Mexican firms.

Table 3

Quintile Regression for the Effect of Authority $(\mathrm{N}=326)$

\begin{tabular}{|c|c|c|c|c|c|c|}
\hline \multicolumn{7}{|c|}{ Identification } \\
\hline \multirow[t]{2}{*}{ Variables } & \multicolumn{2}{|c|}{0.25} & \multicolumn{2}{|c|}{0.5} & \multicolumn{2}{|c|}{0.75} \\
\hline & Coef. & Std. Err & Coef & Std. Err & Coef. & Std.Err \\
\hline \multicolumn{7}{|l|}{ Control Variables } \\
\hline Gender & -0.05 & 0.32 & 0.13 & 0.19 & -0.04 & 0.15 \\
\hline Education & 0.40 & 0.15 & 0.17 & 0.09 & 0.01 & 0.07 \\
\hline Time & 0.00 & 0.02 & 0.00 & 0.01 & -0.00 & 0.01 \\
\hline Position & -0.11 & 0.25 & 0.10 & 0.15 & -0.06 & 0.12 \\
\hline \multicolumn{7}{|l|}{ Leadership } \\
\hline Benevolent & 0.22 & 0.26 & 0.34 & 0.15 & 0.22 & 0.11 \\
\hline Moral & -0.21 & 0.43 & -0.12 & 0.25 & -0.26 & 0.21 \\
\hline Authoritarian & 0.13 & 0.20 & 0.10 & 0.12 & 0.02 & 0.10 \\
\hline Transformational & 0.37 & 0.32 & 0.35 & 0.19 & 0.43 & 0.14 \\
\hline Constant & 0.05 & 1.05 & 0.51 & 0.67 & 2.97 & 0.56 \\
\hline Number of Obs & 218 & 218 & 218 & 218 & 218 & 218 \\
\hline Pseudo R2 & 0.04 & 0.04 & 0.01 & 0.01 & 0.04 & 0.04 \\
\hline \multicolumn{7}{|c|}{ Compliance } \\
\hline & \multicolumn{2}{|c|}{0.25} & \multicolumn{2}{|c|}{0.5} & \multicolumn{2}{|c|}{0.75} \\
\hline & Coef. & Std. Err & Coef & Std. Err & Coef. & Std.Err \\
\hline \multicolumn{7}{|l|}{ Control Variables } \\
\hline Gender & 0.52 & 0.23 & 0.11 & 0.13 & 0.09 & 0.18 \\
\hline Education & 0.14 & 0.12 & 0.07 & 0.06 & 0.01 & 0.09 \\
\hline Time & -0.00 & 0.01 & 0.00 & 0.01 & 0.00 & 0.15 \\
\hline Position & 0.35 & 0.17 & 0.16 & 0.10 & -0.00 & 0.14 \\
\hline \multicolumn{7}{|l|}{ Leadership } \\
\hline Benevolent & 0.58 & 0.19 & 0.53 & 0.10 & 0.21 & 0.15 \\
\hline Moral & -0.16 & 0.34 & 0.06 & 0.17 & -0.37 & 0.25 \\
\hline Authoritarian & -0.03 & 0.15 & -0.04 & 0.08 & 0.12 & 0.13 \\
\hline Transformational & 0.16 & 0.26 & 0.17 & 0.13 & 0.59 & 0.18 \\
\hline Constant & -0.00 & 0.76 & 0.70 & 0.47 & 2.28 & 0.72 \\
\hline Number of Obs & 220 & 220 & 220 & 220 & 220 & 220 \\
\hline Pseudo R2 & 0.16 & 0.16 & 0.11 & 0.11 & 0.08 & 0.08 \\
\hline \multicolumn{7}{|c|}{ Gratitude } \\
\hline & \multicolumn{2}{|c|}{0.25} & \multicolumn{2}{|c|}{0.5} & \multicolumn{2}{|c|}{0.75} \\
\hline & Coef. & Std.Err & Coef. & Std. Err & Coef. & Std.Err \\
\hline \multicolumn{7}{|l|}{ Control Variables } \\
\hline Gender & 0.20 & 0.24 & 0.12 & 0.16 & 0.17 & 0.19 \\
\hline Education & 0.17 & 0.12 & 0.07 & 0.08 & 0.06 & 0.09 \\
\hline Time & 0.14 & 0.02 & 0.02 & 0.01 & -0.01 & 0.01 \\
\hline Position & -0.04 & 0.18 & 0.12 & 0.13 & 0.05 & 0.16 \\
\hline \multicolumn{7}{|l|}{ Leadership } \\
\hline Benevolent & 0.32 & 0.20 & 0.44 & $0.13 * *$ & 0.13 & 0.15 \\
\hline Moral & -0.12 & 0.31 & -0.10 & 0.21 & -0.08 & 0.26 \\
\hline Authoritarian & 0.01 & 0.15 & -0.13 & 0.10 & 0.07 & 0.15 \\
\hline Transformational & 0.60 & 0.25 & 0.52 & $0.16^{*}$ & 0.47 & $0.20^{*}$ \\
\hline Constant & -0.33 & 0.89 & 0.66 & 0.58 & 2.55 & $0.72 * *$ \\
\hline Number of Obs & 219 & 219 & 219 & 219 & 219 & 219 \\
\hline Pseudo R2 & 0.23 & 0.23 & 0.18 & 0.18 & 0.03 & 0.03 \\
\hline
\end{tabular}




\section{Conclusion}

This study emphasized on how paternalistic and Western leadership exercises had a positive impact on the subordinates such as identification, compliance, and gratitude. It conducted several specifications of quintiles to show the relationship between the subordinates' responses in terms of attributes such as identification, compliance, and gratitude. Control variables such as gender, education, and position are relevant human capital and power proxies and might influence on subordinates' reactions toward their leaders depending on their magnitude. The firm's time was not relevant to the subordinates' responses. Benevolent leadership had a significant positive impact on the compliance and gratitude of subordinate respondents. It was a key variable of paternalistic leadership which had a significant positive impact on Peruvian sample under investigation. Furthermore, Western leadership, as peroxide for transformational leadership, had a significant positive impact on subordinates' gratitude. The results of this study were not consistent with the results of empirical studies and the previous literature which were conducted in China and Mexico. This is very helpful in formulating the current human resource management (HRM) policies in the Peruvian territories which is an emerging market despite of informality problems in the labor sector. Also, this contribution may help promote the objectives and provide guidelines for employers and employees.

\section{References}

Anderson, K. (2005). An exploration of the barriers which impede the effective implementation of servant leadership in Latin American evangelical organizations: A grounded theory study (Unpublished doctoral dissertation). Miami, FL: Barry University.

Arbaiza, L. (2011). Economía informal y capital humano en el Perú. Segunda edición, Lima: Universidad ESAN.

Bass, B. M. (2000). The future of leadership in learning organizations. Journal of Leadership \& Organizational Studies, 7(3), $18-40$.

Boyer, C. (2000). The threads of class at La Virgen: Misrepresentation and identity at a Mexican textile mill, $1918-1935$. American Historical Review, 105(5), 1576-1598.

Cheng, B. S., Chou, L. F., \& Farh, J. L. (2004). Paternalistic leadership and subordinate responses: Establishing a leadership model in Chinese organizations. Asian Journal of Social Psychology, 7(1), 89-117.

Carter, M. Z., Armenakis, A. A., \& Field, H. S. (2012).Transformational leadership, relationship quality, and employee performance during continuous incremental organizational change. Journal of Organizational Behavior, 34(7), 942-958.

Cote, J. (2003). El liderazgo de Jesús [The leadership of Jesus]. Lima, Peru: Puma.

Eagly, A. H., Johannesen-Schmidt, M. S., \& Van Engen, M. L. (2003). Transformational, transactional, and laissez-faire leadership styles: A meta-analysis comparing women and men. Psychological Bulletin, 129(4), 569-591.

Davila, A., \& Elvira, M. (2005) Culture and human resource management in Latin America. In M. Elvira, \& A. Davila (Eds.), Managing human resources in Latin America (pp.3-24). London: Routledge.

Farh, J. L. \& Cheng, B. S. (2000). A cultural analysis of paternalistic leadership in Chinese organizations. In J. T. Li, A. S. Tsui, \& E. Weldon (Eds.), Management and organizations in the Chinese context (pp. 94-127). London: Macmillan.

Graen, G. B., Novak, M. A., \& Sommerkamp, P. (1982). The effects of leader member exchange and job design on productivity and satisfaction: Testing a dual attachment model. Organizational Behavior \& Human Performance, 30(1), $109-131$.

House, R. J., Hanges, P. J., Javidan, M., Dorfman, P. W., \& Gupta, V. (2004). Leadership, culture, and organizations: The GLOBE study of 62 societies. Thousand Oaks, CA: Sage Publications.

Katou, A. (2015). Transformational leadership and organizational performance: Three serially mediating mechanisms. Employee Relations, 37(3), 329-353.

Lewin, K., \& Lippiit, R. (1938). An experimental approach to the study of autocracy and democracy: A preliminary note. Sociometry, 1, 292-340.

Mayers, M. K. (1976). A look at Latin American lifestyles. Dallas, TX: Summer Institute of Linguistics. 
McIntosh, T. A., \& Irving, J. A. (2010). Evaluating the instrument de contribution al liderazgo de siervo (ICLS) for reliability in Latin America. The Journal of Virtues \& Leadership, 1(1), 330-49.

Nida, E. A. (1974). Understanding Latin Americans: With special reference to religious values and movements. South Pasadena, CA: William Carey Library.

Patterson, K. (2003). Servant leadership: A theoretical model (Unpublished doctoral dissertation). Regent University, Virginia Beach, Virginia.

Ruloff, E. (2006). El líder siervo: La esencia del líder es le character de Cristo [The servant leader: The essence of the leader is the character of Christ]. Buenos Aires, Argentina: Alianza Publicaciones.

Segura, H. (2005). Más allá de la utopía: Liderazgo de servicio y espiritualidad Cristiana [Beyond utopia: Leadership and Christian spirituality]. San José, Costa Rica: Kairos Ediciones.

Serrano, M. (2006). Servant leadership: A viable model for the Panamanian context? (Unpublished doctoral dissertation). Regent University, Virginia Beach, Virginia.

Silin, R. F. (1976). Leadership and values. Cambridge, MA: Harvard University Press.

Tornell, A., Westermann, F., \& Martinez, L. (2004). The positive link between financial liberalization, growth, and crisis (Working paper No.1164). Retrieved from the CESiFO website: WWW. CESiFO.de

Van Vugt, M., Hogan, R., \& Kaiser, R. (2008). Leadership, followership, and evolution: Some lessons from the past. American Psychologist, 63(3), 182-196.

Yukl, G. (2002). Leadership in organizations ( $2^{\text {nd }}$ ed.). Englewood Cliffs, NJ: Prentice Hall. 